\title{
GERMAN ART ABOUT WAR TODAY AND A CENTURY AGO:
}

\section{A Curator's View}

\author{
Martin Bayer \\ Wartist \\ www.wartist.org, bayer@wartist.org
}

\begin{abstract}
The First World War was a true caesura for mankind, also including the world of art. In its beginning, most German artists supported it, similar to many other intellectuals. The realities of the first global war turned artists such as Ernst Barlach into pacifists. Especially in Germany, expressionism was often chosen to address the horrors of war. Today, only a few artists are still well-known, such as Otto Dix, while the majority and their powerful works need to be rediscovered. German pacifism is deeply rooted in the dreadful experiences of both World Wars, and not the least of bearing the responsibility of those wars, the European division of the Cold War, and the Holocaust. 70 years after the end of the Second World War, pacifism is still strong in Germany - even to the extent that people shun away from securitypolitical realities. But while you might not be interested in war, war may be interested in you. Thus, how do German artists cope with war and peace today, which conflicts are addressed and which approaches are used? To what an extent is the Great War still a subject of German art - now, in its centenary that is such a massive issue in countries like Australia, Belgium, France and the UK? How has global terror influenced German art? As perpetual chameleon, war always adapts itself to changing realities. Artists will continue to transform these societal conditions into moving works.
\end{abstract}

\section{Keywords}

9/11, Bundeswehr, contemporary art, cultures of commemoration, First World War, Germany, terrorism

\section{About the Author}

Martin Bayer works in the fields of civic education and the cultural dimension of war. One of his main subjects is the First World War about which he also wrote a study for the German Foreign Office. His project Wartist (www.wartist.org) includes a bilingual blog website on war and the arts and curating various art exhibitions. He holds a BA in War Studies from King's College London and a Master of Peace and Security Policy Studies from the Institute of Peace and Security Policy Studies at the University of Hamburg, as well as a professional education as photographer from Lette-Verein Berlin. He lives and works in Berlin, Germany. 
With the centenary of the First World War, many exhibitions and media productions reminded an interested audience in Germany of the first truly global conflict and its consequences. Beyond artefacts, historic photos and films or reenacted scenes, numerous artworks were presented to show the effects the modern warfare had on the soldiers. Impressionist painters such as Theodor Rocholl (18541933), famous for his battle scenes of the $19^{\text {th }}$ century, failed to transfer the new levels of chaos and destruction: Even when he painted Tote Deutsche und Verwundete in einem Schützengraben (dead Germans and wounded in a trench, 1914), the horror and suffering seemed to be strangely absent. Thus, new forms of art established themselves. In Germany, the emphasis was on different forms of expressionism, with Otto Dix (1891-1961) surely being the most famous artist who dealt with the First World War, both during the conflict and in the post-war period.

A century later, Germany, its society and the art scenes are highly different. Are war and peace still subjects of contemporary art in Germany, some 25 years after the end of the Cold War and German reunification, 75 years after the beginning of the Second World War, and now 100 years after the outbreak of the First World War? How are today's wars being depicted, and which subjects are addressed? To what extent is the Great War an issue of German contemporary art at all, now, in the centenary of the Great War, being a huge subject in Australia, Belgium, France and the UK? This paper presents the view of a curator who specifically works on subjects such as war and the cultures of commemoration.

First and foremost, pacifism is strong in Germany, especially after the caesura of the Second World War and the National Socialist dictatorship. 1945 was not the foundation of German pacifism, though: taking aside a rather small pacifistic movement in the latter stages of Imperial Germany in the late $19^{\text {th }}$ and early $20^{\text {th }}$ century, pacifism was widespread after the First World War and its millions of victims. Many artists who had openly supported the First World War at its beginning had changed their minds when they had encountered the realities of modern warfare. Ernst Barlach, who is rightly known for his pacifist works, compared his experience as a soldier in autumn 1914 with "a great love affair" (Rother 86). His lithography Der Heilige Krieg (the holy war), published in the same year in the propagandistic Kriegszeit (time of war) magazine, presents a warrior who is calmly preparing a blow with his sword. He is not wearing a modern uniform, but a rather antique-looking tunic. The warrior's face is self-composed, as is his whole posture. There is no reference to an enemy, but the forthcoming fighting takes place without visible aggression; it is rather a necessity, forced by exterior reasons.

Two years later, Barlach's work Aus einem neuzeitlichen Totentanz (from a modern danse macabre) is similarly composed: There is again a warrior wielding a weapon, clad in a simple tunic. This time, however, the warrior has lost his senses: 
he wields his heavy hammer with pure rage, crushing what is left of the skeletons on the ground, focusing on the encompassing destructive powers of war. This warrior does not need an enemy; war as such is enough to fuel his rage. While in the case of the previous work, peace could simply be installed by taking down the arms on both sides, reconciliation or consolation seem to be impossible in the 1916 work. War, indeed, has eaten up reason. The experience of it, nevertheless, has changed the artist and made him a pacifist, proven by his later works such as the memorial to the fallen in the Magdeburg cathedral. From 1914 to 1918, some 2,037,000 German soldiers had been killed, some 700,00o civilians perished (mostly due to the naval blockade), and millions more had been affected: maimed, traumatised or confronted with the loss of loved ones (Hirschfeld, Krumeich, and Renz 664-665).

Most German artworks that depict or respond to the First World War that are well-known today stem from the post-war period: both the triptych (1932) and the portfolio (1924) Krieg (war) by Otto Dix, the scathing works by George Grosz holding up a mirror to the divided post-war society - or the accusatory works of Käthe Kollwitz who had lost her own son Peter in the Great War." "Nie wieder Krieg!" (no more war), as in one of Kollwitz's works, was a common slogan. One may remember Dix's Sturmtruppe geht unter Gas vor (storm troopers advance during a gas attack) from the "war" portfolio: The soldiers are not human individuals any longer, wearing their frightful gas masks that dehumanise their faces and both reduce and enlarge their eyes to huge glasses. Even more so, they directly advance to the viewer, as if it were the last moment one could see just before being clubbed, stabbed and shot to death. The end is nigh! And it was the end of civilisation that many soldiers sensed during the Great War: already by 1915, it felt endless, but it still continued for three more bloody years.

But the difficult socio-economic situation and the cross-societal disappointment with the Versailles Treaty were factors to fuel extremism, unhindered by the faults of the first German democratic republic's constitution. Even although the beginning of the Second World War was far from being welcomed by the Germans (contrary to Nazi propaganda), the comparably quick successes of the campaigns in Poland (1939) and France (1940) led to a widespread view that war could pay off, that national humiliation could be revoked, and that through dictatorship and war, Germany could be a strong nation again. Just some years later, however, Germany was heavily destroyed and even more millions of soldiers and civilians were dead. The National Socialist dictatorship would become the main issue of both international and national perception of Germany. Pacifism became heavily embossed into the German psyche: "no more war" was not just another fashionable slogan. Just a decade after the end of the Second World War, when the Western Federal Republic of Germany became a member of NATO and the Eastern German Democratic Republic part of the Warsaw Pact, the question of setting up new armed 
forces became eminent. In the democratic West, there were huge demonstrations against this rearmament: "Ohne mich" (without me!) was one of the slogans, visible on many posters. After the massive destruction of the Second World War that was caused by Germany, after millions of lives lost and millions more displaced, the foundation of new armed forces, the NATO membership, and the introduction of conscription were highly controversial. But realpolitik took its toll, and Germans had to cope with it. Besides the Bundeswehr (federal armed forces) in the West, the Nationale Volksarmee (national people's army) was built up in the East. Up until the mid-196os, however, these protests were hardly reflected by the arts.

Now, 25 years after the reunification of the two German states, and with many Bundeswehr overseas missions for NATO and the UN in mind (including combat missions such as in Kosovo and especially Afghanistan), pacifism is still a main driver in German society. While the armed forces are perceived as a trustworthy part of society, the war in Afghanistan and the German participation is disapproved by between two thirds and three quarters of the population, forming a huge disconnect between these two opinions (Bulmahn and Wenner 43). One of the main issues of this German approach to pacifism is, indeed, its indiscretion: Germany should keep her fingers out of war, even if there is also a "responsibility to protect" within the United Nations. But how can you stop war on your doorstep? International appeasement did not prevent Hitler from invading further countries, and it was only through the declarations of war by Great Britain and France in 1939 that a line to German aggression and expansionism could be drawn. In 2005, Federal President Horst Köhler called the German approach to war and peace, on defence and security "friendly ignorance", referring to the huge lack of knowledge about world politics on one hand and the isolationist preference on the other. A few years later, he had to step down over his statements that the German armed forces should be used to secure German interests. The current Federal President Joachim Gauck has already been fiercely attacked for being a "war monger": he dared to state that Germany has to take responsibility and not to rely on others all the time when it comes to security issues. In the 1990s Gulf War, Germany did not send soldiers, but preferred to buy its way out through "cheque book diplomacy." A similar behaviour would not be any longer accepted within NATO, the EU or the UN.

It is this indifference of large parts of the population that the author is working against, for example, through exhibitions of contemporary art that address war or the cultures of commemoration. What becomes part of the collective memory? How does the public remember wars? Are the protagonists and their actions forgotten, and if not, how are they being remembered? In Germany, the main focus of memory is on the Second World War and the Holocaust. This may hardly surprise, taking into account both the monstrosity of crimes committed and the 
losses and grief suffered. Vergangenheitsbewältigung (dealing with one's past) became a German word, and it can be done on very personal as well as public levels. The strong focus on the period of 1933 to 1945, however, often lacks a heuristic view which would be necessary to fully understand German society of the 1920 s and 1930s. For example, while the First World War continues to be the "Great War" in countries such as Australia, Belgium, France or the United Kingdom, it became a rather forgotten conflict in Germany post-1945, with only some hours of secondary education attached to discussing this period of time in class. In fact, no common narrative of the First World War could be established: East Germany perceived itself as a new state and thus refused to have any connection with either Imperial or Nazi Germany. In Western Germany, plaques were often added to the existing First World War memorials for those who died 1939 to 1945. Those memorials thus became reframed, and on the Volkstrauertag (national day of mourning), the focus is only on the victims of the Second World War and the Holocaust. ${ }^{2}$

Up to 1945, war had been a strong subject in German art in the past 100 years, be it for propagandistic reasons-not the least during the Nazi period-or to remember the sufferings as in the 1920 and early 1930s. After the Second World War, this changed considerably. Many artists had been driven out of Germany by the Nazis; others such as Felix Nussbaum (1904-1944) had been murdered in the concentration camps. The intellectual bloodletting had been immense, and in the post-war period, Germans were more focused on rebuilding Germany, and also desiring to forget. It needed the revolts of the late 196os during the Vietnam War to lead to a substantial change within West German society. Artists such as Anselm Kiefer (born in 1945) provoked the West-German post-war society with showing the Nazi salute as performance, not to present their way of thinking but to remind the Germans about their past and not the least their present time, as many Nazis managed to continue their career after the war. Other artists such as Sigmar Polke (1941-2010), Jörg Immendorf (1945-2007) or Joseph Beuys (1921-1986) showed their support for movements against the Vietnam War, and disturbed the Germans with abstract works. Gerhard Richter (born in 1932) dealt with the proximity of Nazi ideology in one's own family (for example in his blurred painting Onkel Rudi (uncle Rudi), 1965), but also with the aesthetics of war machines: His Mustang Staffel (squadron of Mustang fighter planes, 1964), the Phantom Abfangjäger (Phantom interceptor, 1964) and XL 523 (1964) present the means of destruction as objects of speedy elegance and powerful beauty, thus showing the ambivalence of many weapons.

Turning to war in German contemporary art, it is, indeed, a difficult subject. Of course, war continues to be a huge theme for mankind, even before $9 / 11$, the global war against terrorism and the rise of IS. The art market, however, is focused on saleable art - and works on war do hardly qualify as such in modern democratic 
societies: one only needs to stroll around the annual art shows such as Art Basel, FIAC in Paris or Freeze in London and count the number of works that relate to war. Artists who work with these subjects are asked by their gallery owners about what else they could offer. Curators approaching exhibition spaces are confronted with the rejection of such topics in favour of environmental issues or other, less awkward subjects. Even museums may shun from showing contemporary works about such "difficult" subjects: in the countless exhibitions in Germany on the First World War in 2014, there were only very few contemporary artistic takes to be seen, and if so, one prefers the "view from abroad" such as the Stela, however fascinating a work on commemoration it is. ${ }^{3}$ Not the least, there are increasing cases of fear-based self-censorship. Barbara Duisberg's painting Helmand (2010) was intended for a group show in Berlin, but its curator shunned away from presenting the picture, fearing possible Islamist protests: The picture - based on a press photo - shows an ordinary Afghan peasant who is being frisked by a US soldier. According to this curator, however, this man could be mistaken for Osama Bin Laden, back then still alive and on the loose. Similarly, the Berlin-based opera house Deutsche Oper cancelled Mozart's opera Idomeneo in 2006, with its miseen-scène by Hans Nauenfels showing the severed heads of Buddha, Jesus and Mohammed since there was fear of possible Islamist reprisals. It is such an attitude of pre-emptive obedience and fear that the terrorists want to create. Even more so, it is important for art to take a position. Helmand was then first presented to the public in 2011 as part of the group show Zeitenwende (turning point) on ten years of $9 / 11$ and its consequences, including the Guantanamo camp and the continuing wars in Afghanistan and Iraq. ${ }^{4}$ There, it was surely a reason for vivid discussions, but this exactly is an important reason for art, if it should have a meaning beyond its decorative value or a source of income.

A huge difference between artists a century ago and today is the immediacy of the war experience. During the First World War, nearly all the German artists were soldiers themselves. In contrast to the commissioned artists in countries such as Great Britain or Austria-Hungary, they firstly were soldiers and worked artistically only during their spare time (Küster 2008 48-79). For example, Fritz Steisslinger (1891-1957) appears to be the only known artist who made oil paintings on the front while being a soldier, often using scrap pieces of sackcloth as his canvas (Schneider, Gotttschlich, and Ladleif 227). Similarly, Otto Dix, one of the most famous artists of the Great War, survived the whole war from 1914 to 1918, and was awarded with the Iron Cross $2^{\text {nd }}$ class. Today, artists are hardly at the front lines of contemporary wars; in fact, there are hardly any "front lines" today, where a distinction between battlefields and the civilian sphere have become increasingly blurred. They usually get the images for their works from the media. In addition, and contrary to the USA or the UK, Germany does not have officially commissioned war artists who would be sent on the overseas missions with the soldiers. Surely, the production of 
impressive works of art about war does not necessarily require the artist to endure the suffering, but it is important to remember the different situation a century ago: The media is always a filter, and thus, media images are a selection of one specific view. We usually do not know how long the journalist was there; what access he or she had to the soldiers, the civilians in the area, and the actions as such; what background information was available; or to what extent the press was embedded into the fighting force.

Nevertheless, various contemporary artists address today's or historic wars in their works. Among others, the following selection is based on their engagement with the subject: for these artists, drones are, for example, not reduced to fashionable "it-subjects" that may appear in their pictures to add a feeling of societal relevance. All of them have been deeply touched by war and the effects it has on societies. For many of them, the media-from which they receive the images their works are based upon-is critically assessed, too.

Jens Kloppmann (born in 1969) is one of those contemporary German artists who centre on socio-political issues and especially on the cultures of remembrance (Kloppmann). His "Fries" (frieze) consists of hundreds of fretworks. The silhouettes depict famous scenes or persons of the political sphere: German Chancellor Kohl and French President Mitterand holding hands at the First World War memorial of Verdun in 1984; the girl Phan Thị Kim Phúc who was severely burnt by napalm during the Vietnam War; the German Chancellor's Brandt Warsaw Genuflection; among many other such silhouettes, there are countless "unknown soldiers" from various periods of history, but also figures of pop culture such as R2-D2 or the Beatles crossing Abbey Road. It is for the viewers to remember and connect. What has become collective memory, and how is it chosen?

Kloppmann's series Bullets (since 1999) are plaster casts of Berlin's battle scars. When he moved to the German capital in the early 1990s, he was astonished to find bullet holes from the Second World War in many buildings. After German reunification, these remnants of the past subsequently vanished. Bullets might be mistaken for a serial abstract work, as the holes are presented on a white, plain and smoothed surface. But it is important for the artist that these holes cannot be traced back to a specific location: it might have been a factory, a block of flats or a villa, and at the same time, it cannot be distinguished if the source of these damages were Soviet or German bullets during the Battle of Berlin in spring 1945, or if they had been caused by Allied bombardment: war affects people in the same way - and it should be equally remembered and reflected.

His video installation 6:57 P.M. (2012) refers to the moment when US President George W. Bush returned to Washington on September 9, 2001, hours after the 
disastrous terrorist attacks. After he left his helicopter, he walked to the White House, being watched by the media and thus millions of people. Everybody knew that he had to react, to "do something" - and that the reply would hardly be peaceful. The short loop of 6:57 P.M. consists of Bush walking and walking and walking - and we might ask ourselves if he (or we) ever left this stage, if there was a true direction in the post-9/11 actions, if there is progress beyond pure movement.

Marius Heckmann (born in 1957) also worked on 9/11 as a defining moment of our times (Heckmann). His series of oil paintings "Fading (9/11)" (2007-2013) depicts the planes crashing into the towers of the World Trade Center, the burning buildings, people watching it, but also those who jumped down from the WTC: they chose their own form of certain death, in a both desperate and brave act to defy being suffocated or burnt alive. When the artists and the curator hung these works in the group show Zeitenwende (turning point) at the German broadcaster's ARD capital studio in $2011,{ }^{5}$ there was quite a discussion with its employees: Some of them were opposing this series, depicting dying people "which you must not do." On a panel discussion, the artists pointed out that it was the media who showed these images of death and destruction for weeks and months - and now, a decade after this event, should it be unethical to remember the victims? Heckmann's series also includes a portrait of those who jumped, as well as a woman covered in dustfurther media images that are part of the world's collective memory.

On the same group show, Monika Anselment presented two of her series: $T V$ Wars and Le Cauchemar de M.A. $\neq$ le Cauchemar des USA (the nightmare of M.A. $\neq$ the nightmare of the USA) (Anselment). Again, both make use of media images: The former consists of screenshots of war fighting shown on TV screens since the 1990s. Without their context as media pictures from various wars, these images could be caused by natural events or bonfires. In fact, the scenes depicted tend to be intriguingly beautiful, and it is this aestheticization of war as well as the interchangeability and arbitrariness of news images that the artist is criticizing. The latter work deals with the collective perception and the world's visual memory: the photos show low-flying planes, with the camera angle suggesting it may crash into a high building. Before $9 / 11$, this would be merely seen as a trick of the senses or at worst an accident going to happen, but since 2001, this series brings up images of destruction and fear.

Barbara Duisberg (born in 1961) equally uses media images for her works: with the background knocked out, individual characters seem to float on a gold-plated surface, a trademark of her works. Again, a context is needed for us to assess and understand the pictured event - and this context is usually given by the media we choose, be it a posting on Facebook by somebody who "was sent the image by a friend in the area" or a more trustworthy source. Kosovo shows international 
policemen after the Kosovo war, without any scenery. What took place when this photo was taken? In the end, it is the same level of information available to the viewer as in the original press photo - the scenery thus is reduced to sheer decoration. But what is the "truth", the "reality", the "authenticity" we always strive for?

The works of Jan Bejšovec (born in 1975 in then-Eastern Germany) are made from textiles, sewn together, with applications or embroidery added, and nearly always addressing socio-political issues such as German unification. His Tyrannenmord (tyrannicide) makes use of the media image of Muammar al-Gaddafi just after his murder. Films were aired worldwide showing the much-hated Libyan dictator as captive, being filmed by mobile cameras, increasingly realising his subsequent death. On the next day, many newspapers showed the image of the dead tyrant's face, only for it to vanish a few days later from the public sphere. How much dignity do we allow to people, even to those who robbed others of theirs? The work's abstracted face is surrounded by Arab applications and various camouflage patterns (used by the Libyan forces) as well as blood red fabrics in which both the dictator and the country seem to have drowned.

Katharina Arndt (born in 1977) and Gero Neumeister (born in 1968) formed the artist collective Extraschrot (extra shot). ${ }^{7}$ Their works included the light installation Pax vobiscum (peace be with you, 2007) and the video installation "I $\vee$ NY" (2010). The latter consists of various film clips from disaster or science fiction movies in which New York gets destroyed again and again, accompanied by Johann Sebastian Bach's soothing Air from his $3^{\text {rd }}$ orchestral suite. Even though people know that it is "just some movies", they frequently broke into tears during Zeitenwende, as the emotional links to the grim reality were too strong. The former is a clever approach to the meaning of peace: the light installation formed the iconic silhouette of an Avtomat Kalashnikova AK-47 assault rifle. This weapon could be referred to as today's true weapon of mass destruction: lacking accuracy, but highly robust and easy to use and maintain, it is used in its different versions in countless conflicts in the world, from Afghanistan to Somalia. The installation was hung at the Berlin Zwingli church, similarly to the ubiquitous illuminating decorations during Christmas time. Christmas, is a celebration of peace - but all the symbols have become meaningless and interchangeable, the timeless and important message replaced by a global multi-billion "Xmas" market. The installation's Latin title Pax vobiscum not only refers to the difficulties of bringing peace by force, but also to the misuse of religions to instigate conflicts around the world.

Since the early 20oos, Marcus Wittmers (born in 1973) made a series of sculptures out of disused gravestones in which he realistically chiselled modern infantry weapons such as M4, SA8o or AK-47 assault rifles, Uzi machine pistols or 
Beretta or Colt handguns (Gitte Weise Gallery). While the names of the deceased people are erased, former captions such as UNVERGESSEN (unforgotten) can still be read. Its German title Waffenruhe (literally armistice) congenially refers to the weapons being put to rest, too. Not the least, weapons were and are aestheticized by the media and the arts - but in real life, the result of their usage is always death.

Michael Sailstorfer (born in 1979) has become quite successful with his installations and sculptures that often include a certain level of absurd humour (Artnet). His Tank (T-72) of 2010 is based on a commercial dummy tank. With costs of just some $5,000 €$, such dummies simulate the appearance of a tank (visually or even including the heat signatures). During the Kosovo War in 1999, NATO aircraft destroyed more Serbian "tanks" than they actually had - or, better to say: highly accurate (and expensive) missiles often hit such cheap Chinese dummies of Soviet-built tanks. For the artist, it was far from being easy to buy such a dummy, as customers are states, not individuals; even more so, as he wanted the cannon to be slightly bigger than the original. In his installation, the rubber tank is inflated to its full life-size, only to be deflated again. From a symbol of might, it turns into a sign of (including manly) weakness, when the support for the main cannon has gone. It is just a small step from alleged prowess and strength to ludicrousness.

Simon Menner (born in 1978) made a series of photos called "Camouflage" (Menner). At first glance, they are simple and nice landscapes, harmless and decorative. At the second look - they are still nice landscapes. It is the title of the series and the description of the images that is intended to change the viewer's perceptions: in each image, in each landscape, a Bundeswehr sniper team is hiding, pointing their rifle to the photographer and thus the viewer. How does this knowledge affect the viewer, if at all? In any case, the series is not a simple game of hide-and-seek, even if many viewers try to find the camouflaged soldiers. Indeed, the sniper teams remain invisible, sometimes with the exception of a fake position that has been set up by the army sniper team. These images also refer to modern warfare, fought without clear frontlines. Be it in Sarajevo during the Balkan Wars or in Herat or Aleppo today - a calm situation may turn into a deadly war zone in just a second. Are you already a target, or will you be one?

Jo Röttger (born in 1954) is one of the few contemporary artists who actually went into a war zone (Röttger). He accompanied a company of Bavarian mountain troops to their training in Eastern Germany, to their ISAF mission in Afghanistan, and - after their return - to their home base in picturesque Bavaria. He did not choose a small, versatile digital camera, but a clumsy, old-fashioned large-format camera. The quality of the results is impressive, as is the approach through landscapes - in which the traces of war are always visible - to the image of soldiers, homeland, national and individual identity and ultimately memory. Somewhere 
in Afghanistan, a soldier is standing at the ready, looking like an alien high-tech element in an archaic landscape. A boy is passing him, walking a bike with flowers. Maybe the boy will just pass on, not caring about the soldier at all. Maybe he will stop and give or try to sell him one of his flowers. Or maybe he will bring an improvised explosive device to detonation, killing himself and an "infidel." The soldier does not know. He tries to be both approachable and ready to counter any threat. We can only try to envisage the individual stress on both the soldiers and the civilians who have to live in such conditions of constant insecurity. That is one of the realities of today's wars, also covered in this series.

Till Ansgar Baumhauer (born in 1972) - who went to Afghanistan for about a year, taking part in the reopening of the Afghan National Museum - still works on a series called Entknüpfungen (literally "de-knotting") for which he takes away the knots of Afghan rugs to form symbols (Baumhauer). "When working and fighting in these countries, we leave our traces there," he said, and thus he chose symbols such as the Federal Eagle or the Iron Cross (as the Bundeswehr logo). ${ }^{8} \mathrm{He}$ also refers to the old tradition of rug making in Afghanistan, including so-called "war rugs": since the Soviet invasion, aspects of modern warfare, from tanks to assault rifles, and from aircraft to helicopters, are included in the traditional patterns, some of them highly abstract, others quite realistic, depending on the specific area and school of rug makers. The artist, however, would never use such rugs for his Entknüpfungen series, as they are already highly charged with symbolism, without the need of another layer of meanings. ${ }^{9}$

In Germany, remembering the Great War is highly overlaid by the Second World War with its even larger rupture of civilisation, and the division into two highly different German states as one of its outcomes (Bundeszentrale 47-48). There are some contemporary German artists though who address this first global war in various forms. For many it is a fascination with a specific part history that (at least until the centenary of the war's outbreak) was basically unknown to many Germans. During their process of developing their works, the artists began to understand the war's importance for world and German history, and they questioned the public memory of this pivotal conflict.

Chris Dreier approached Verdun, the site of the largest battle between French and German forces in the First World War (Dreier). This battle continues to be of primary symbolic importance for both countries (similar to the Battle of the Somme for the British or Gallipoli for the Australians), and Verdun became synonymous with senseless slaughter. Her series Souvenirs de Verdun (together with Andreas Seltzer, who made drawings around the many tourist guides that were published soon after the armistice) consists of photos of today's landscapes made with a pinhole camera. The appearance is thus specific, with the whole photo 
being in focus while being somewhat blurred at the same time, giving it a ghastly look; be it an overgrown trench, a bunker or a harmless-looking grove that once was the area of fierce fighting. What remains of such a symbolically burdened place that partly is still uninhabitable due to the massive contamination with explosives, heavy metals, gas and other remnants of war? Or is it the absence of humans that lets nature recapture the landscapes again, making room for new life after the destructive period of mankind?

Robert Schneider's (born in 1944) huge body of works centres on socio-political issues, including his Verdun cycle of 42 charcoal drawings, also addressing this symbolic battle (Schneider). Applying a realist style, he made landscapes of today's area of Verdun, only to condense what he saw and felt when visiting these places. They are thus not a mere (if exact) black and white picture of what could be simply photographed, but an artistic condensate: without showing a single corpse, one can feel the amounts of blood that once flooded this area. Schneider's artistic approach works equally well when dealing with such diverse issues as Nazi concentration camps, forced labour, terror, natural resources, environmental pollution or the downfall of heavy industry in central Europe.

Alexander Seiler calls his works Archiskulpturen, as architectural elements such as Doric columns have a strong influence on his sculptures (Seiler). The work Panthersprung refers to the "panther's leap to Agadir," part of the Second Moroccan Crisis in 1911, another incident of clumsy gunboat diplomacy before the Great War when Imperial Germany sent the armed vessel Panther to support its wish for influence. Seiler's sculptured ship, however, is far from being a symbol of might. In fact, it looks decayed, with its pillar-shaped gun barrels feebly pointing downwards, with a corroded hull and a derelict superstructure. Seiler is pointing to what he sees as the contemporary decline of culture (with war being a catalyst of such a downfall) and to those who deny its existence.

For decades, Asmus Petersen (born in 1928) has been visualising the movements of ships in sea battles (Petersen). On the first view, the results appear to be abstract reductions to arrows and lines, but again, the specific titles may make the first difference for a viewer. The Battle of Jutland, 31 May 1916, between 172oh and $1748 \mathrm{~h}$ depicts exactly that situation when the British Home Fleet and the German High Seas Fleet met in the foggy waters around the Danish coast. The only major sea battle of the First World War was basically a draw, although both participants claimed it a victory: the British, as the German fleet had withdrawn, and the Germans, as they had inflicted more casualties with their fleet's inferior force. There are no visible battlefields left at the oceans, and hardly any memorials remember these events. Under the surface, there may be wrecks and the remnants of thousands of sailors, but they all vanished from our visibility-and also from our memory? 
One should not forget about new forms of media, too. The graphic designer Peter Eickmeyer (born in 1964) published his graphic novel version of Erich Maria Remarque's famous anti-war book Im Westen nichts Neues (All Quiet on the Western Front) in 2014 (Eickmeyer). Keeping some quarter of the original text, he visualised many of the stories included in the book. A strong example is surely the close-up view of parts of the protagonist's face, fearfully watching a German soldier bayoneting his French enemy, mirrored in his wide open eyes.

The given list of artists could be, of course, continued with several other contemporary artists. This underlines the fact that war is still an important subject of German contemporary artists, even including the First World War that is otherwise overshadowed by later events in the German cultures of commemoration. This result is quite contrary to the German art market, where such works are hardly to be seen at the annual art shows in Cologne or Berlin, for example. Having said that, artistic works such as the ones mentioned are highly necessary, since the societal discussions on war and peace, defence and security, terror and freedom are dearly needed. This refers not the least to Germany, a country with, on one hand, economic might, but, on the other, with lots of societal restraints to accept political responsibility. Furthermore, while so much societal effort has been put into addressing the Nazi dictatorship, the Second World War and the Holocaust, other parts of German history still need to be understood. Only then, German society may better understand the motivations of the neighbouring countries for which for example the First World War still remains the "Great War." Works such as those described remind civil society that wars are still present, too, even if they may have vanished from the TV screens, with other news having become more "important." Equally, another task of these unique works is to remind the public how central history is in forming general perceptions of ourselves and others. Not the least, war is and remains a central issue for mankind, or, in the words of the Greek philosopher Plato: "Only the dead have seen the end of war." Contemporary art, thus, has a chance to make a stand, to discuss and be provocative about these "difficult" issues, and to stay relevant as lasting artistic outcomes, beyond a solely economic approach within a global arts market. 


\section{Notes}

1. Unlike her husband, Käthe Kollwitz had supported her son in his wish to volunteer - in late October 1914, he had died in Flanders. Kollwitz's grandson Peter, named after his uncle, later died in the Second World War.

2. Since 1952, Volkstrauertag is two weeks before the first Sunday of Advent.

3. Stela by Kingsley Baird from New Zealand was shown at the Militärhistorisches Museum der Bundeswehr (military historical museum of the German armed forces) in Dresden in 2014 (Stela)

4. Zeitenwende at ARD-Hauptstadtstudio (Zeitenwende)

5. ARD is the primary German public-sector broadcaster.

6. Discussions between the curator Martin Bayer, some artists and some ARD employees during the installation of Zeitenwende exhibition, August 29-31, 2011.

7. Information about the artists can be retrieved from the Internet (Arndt, Neumeister)

8. Opening of the exhibition "Collateral Creativity," September 28, 2012, Gallery OKK, Berlin

9. Also in the opening of the exhibition "Collateral Creativity," September 28, 2012, Gallery OKK, Berlin 


\section{Works Cited}

Aichner, Ernst, ed. Der Erste Weltkrieg - Zeitgenössische Gemälde und Graphik. Ingolstadt: Donau Kurier Verlag, 1980. Print.

Anselment, Monika. monika-anselment.net. Web. 20 Feb. 2016.

Arendes, Cord and Jörg Peltzer, eds. Krieg - Vergleichende Perspektiven aus Kunst, Musik und Geschichte. Heidelberg: Universitätsverlag Winter, 2007. Print.

Arndt, Katharina. katharina-arndt.com. Web. 2o Feb. 2016.

Artnet. <http://www.artnet.de/galerien/galleri-k/k\% $\mathrm{C}_{3} \% \mathrm{BCnstler-michael-sailstorfer/>.}$ Web. 7 Mar. 2016.

Baumhauer, Till Ansgar. till-ansgar-baumhauer.de. Web. 2o Feb. 2016

Bechtloff, Dieter, ed. Kunst und Krieg, Kunstforum international, vol. 165, Ruppichteroth: tz-Verlag, 2003. Print.

Bulmahn, Thomas and Meike Wenner. Forschungsbericht zur Bevölkerungsumfrage 2013 zum Image der Bundeswehr sowie zur Wahrnehmung des Claims "Wir. Dienen. Deutschland." Potsdam: ZMSBw, 2013. Print.

Bundeskunsthalle Bonn, ed. 1914 - Die Avantgarden im Kampf. Köln: Snoeck, 2013. Print.

Bundeszentrale für politische Bildung, ed. Aus Politik und Zeitgeschichte: Erster Weltkrieg, vol. LXIV, No. 16-17/2014. Bonn: Bundeszentrale für politische Bildung, 2014. Print.

Dreier, Chris. Pinhole Shots 200o-2011. Berlin: Fantôme, 2011. Print

Dreier, Chris. <http://chrisdreier.de/tolstoy/galerien/Verdun/?t=Verdun >. Web. 20 Feb. 2016.

Eickmeyer, Peter. petereickmeyer.wordpress.com. Web. 2o Feb. 2016.

Gitte Weise Gallery. <http://www.gitteweisegallery.com/wittmers>. Web. 20 Feb. 2016.

Heckmann, Stefanie and Hans Ottomeyer, eds. Kassandra - Visionen des Unheils 19141945. Dresden: Sandstein Kommunikation, 2009. Print.

Heckmann, Marius. marius-heckmann.de. Web. 20 Feb. 2016.

Hirschfeld, Gerhard, Gerd Krumeich, and Irina Renz, eds. Enzyklopädie Erster Weltkrieg, second edition. Stuttgart: UTB Verlag, 2014. Print.

Jürgens-Kirchhoff, Annegret. Schreckensbilder - Krieg und Kunst im 2o. Jahrhundert, Berlin: Dietrich Reimer, 1993. Print.

Kloppmann, Jens. kloppmann.org. Web. 2o Feb. 2016.

Küster, Bernd. Heinrich Vogeler im Ersten Weltkrieg. Bremen: Donat, 2004. Print.

Küster, Bernd, ed. Der Erste Weltkrieg und die Kunst: Von der Propaganda zum Widerstand. Gifkendorf: Merlin, 2008. Print.

Mackert, Gabriele, Gerald Matt, and Thomas Mießgang, eds. Attack - Kunst und Krieg in den Zeiten der Medien. Wien: Steidl, 2003. Print.

Menner, Simon. simonmenner.com. Web. 2o Feb. 2016.

Neumeister, Gero. geroneumeister.com. Web. 2o Feb. 2016.

Nöring, Hermann, Thomas F. Schneider, and Rolf Spilker, Rolf, eds.. Bilderschlachten 2000 Jahre Nachrichten aus dem Krieg. Göttingen: Vandenhoeck \& Ruprecht, 2009. Print. 
Petersen, Asmus. „Bilder des Krieges/Art of War.“ $<$ http://www.asmus-petersen.de/Bilderdes-Krieges/Nordsee/Seeschlacht-vor-dem-Skagerrak.php>. Web. 20 Feb. 2016.

Reiss, Ansgar, and Martin Bayer, eds. Jo Röttger - Landscapes \& Memory. Berlin: Peperoni Books, 2013. Print.

Rother, Rainer, ed. Die letzten Tage der Menschheit - Bilder des Ersten Weltkrieges. Berlin: Deutsches Historisches Museum, 1994. Print.

Rother, Rainer, ed. Der Weltkrieg 1914-1918 - Ereignis und Erinnerung. Berlin: Edition Minerva, 2004. Print.

Röttger, Jo. joroettger.com. Web. 2o Feb. 2016.

Simon, Jürgen, and Brigitte Jansen, eds. Asmus Petersen - Die Farbe des Krieges. Lüneburg: Heinrich-Heine-Haus, 200o. Print.

Schenk-Weininger, Isabell. Krieg - Medien - Kunst. Nürnberg: Verlag für moderne Kunst, 2004. Print.

Schneider, Gerhard, Ralf Gottschlich, and Christiane Ladleif, eds. Der Erste Weltkrieg im Spiegel expressiver Kunst: Kämpfe - Passionen - Totentanz. Bönen: Stadt Reutlingen, 2014. Print.

Schneider, Robert. „Robert Schneiders Jahrhundertreflexion." Bilder-der-arbeit. Web. 20 Feb. 2016.

Seiler, Shohe Alexander. shohe-alexander-seiler.com. Web. 20 Feb. 2016.

Spilker, Rolf, and Bernd Ulrich, eds. Der Tod als Maschinist - Der industrialisierte Krieg 1914-1918. Bramsche: Rasch, 1998. Print.

Staatsgalerie Stuttgart, ed. Kollwitz - Beckmann - Dix - Grosz. Kriegszeit. Tübingen: Wasmuth, 2011. Print.

Stela. „Kunstprojekt ,Stela“ von Kingsley Baird.“ Militärhistorisches Museum. Web. 20 Feb. 2016.

Uhlitzsch, Joachim. Der Soldat in der bildenden Kunst - 15. bis 20. Jahrhundert, Berlin: Militärverlag der DDR, 1987. Print.

Zeitenwende. „Wartist Presents: Group Show ,Turning Point' on 10 Years of 9/11 at ARDHauptstadtstudio, Berlin." Wartist. 22 Aug. 2011. Web. 20 Feb. 2016. 
